\title{
Colletotrichum dracaenophilum causes anthracnose on Dracaena braunii in Brazil
}

\author{
D. M. Macedo $^{1}$ (i) $\cdot$ R. W. Barreto ${ }^{1}$
}

Received: 15 June 2015 / Accepted: 14 March 2016 / Published online: 22 March 2016

(C) Australasian Plant Pathology Society Inc. 2016

\begin{abstract}
Dracaena braunii (lucky bamboo) is a plant of West Africa widely used as an ornamental. Recently individuals bearing anthracnose symptoms were found in Viçosa (state of Minas Gerais, Brazil). Morphology was typical of Colletotrichum dracaenophilum and sequence analyses indicated a high homology to the internal transcribed spacer region and Beta tubulin with the ex-type sequences of this species. This is the first record in Brazil.
\end{abstract}

Keywords Asparagaceae $\cdot$ Lucky bamboo - Ornamental plant $\cdot$ Plant disease $\cdot$ Taxonomy

The genus Dracaena (Asparagaceae) includes approximately 350 species (Tropicos.org 2013). Dracaena braunii (= D. sanderiana) is a native of West Africa widely cultivated as an indoor ornamental plant (Gunathilake and Abeywickrama 2011). Ornamentals are expected to have an impeccable appearance and disease damage is not acceptable. In Brazil there is limited information on diseases of ornamental plants, even for highly popular and economically important species. In August 2009, stems of D. braunii bought locally and grown in a private residence in Viçosa (Minas Gerais, Brazil) were observed bearing a combination of chlorosis and blackened and pinkish mucilagenous areas apically. These were recognized as anthracnose-like symptoms. There is no fungal pathogen recorded on D. braunii in Brazil (Mendes and Urben

D. M. Macedo

dmmesk@yahoo.com.br

1 Departamento de Fitopatologia, Universidade Federal de Viçosa, Viçosa, Minas Gerais 36570-000, Brazil
2014) and this disease is determined in the present study (Fig. 1).

Samples were dried in a plant press and deposited in the local herbarium Universidade Federal de Viçosa (accession number VIC 39834). Diseased material was examined under a dissecting microscope and found to consistently bear acervuli. Fungal structures were either scraped from the diseased tissues with a scalpel or prepared for sections and mounted in lacto-fuchsin and lactophenol for observations under a light microscope (Olympus BX 51) equipped with an Olympus ${ }^{\circledR}$ E-volt E-330 camera. Pure cultures were obtained by transferring conidia from infected tissue onto vegetable broth-agar - VBA (Pereira et al. 2003), with a sterile fine pointed needle. One culture was deposited in the local culture collection Coleção Octávio de Almeida Drumond (COAD 1115). The fungus was to grown on VBA and potato dextrose-agar (PDA) and incubated at $25 \pm 2{ }^{\circ} \mathrm{C}$ either in the dark or under a $12 \mathrm{~h}$ light regime for culture description. The culture morphology and colour was recorded after 1-week growth and described as a combination of observations made from colonies in all treatments. Colony colour was described according to Rayner (1970). The apressoria were described from slide cultures as described by Gams et al. (1998). Two $7 \mathrm{~mm}$ diam culture plugs obtained from 1-week old cultures formed on VBA were placed on the surface of healthy stems of plants at three different points. Plants were then transferred to a humid chamber for $48 \mathrm{~h}$ at $25^{\circ} \mathrm{C}$ and then taken to the bench of a greenhouse, where they were maintained at approximately $25{ }^{\circ} \mathrm{C}$. Plants sprayed with sterile tap water served as controls.

Total genomic DNA was extracted from mycelium produced in PC (potato-carrot) decoction in steady plates for 1 week, with the Wizard® Genomic DNA purification Kit (Promega corporation, Madison, WI, USA) following the manufacturer's protocols. Isolated DNA was visualized by 


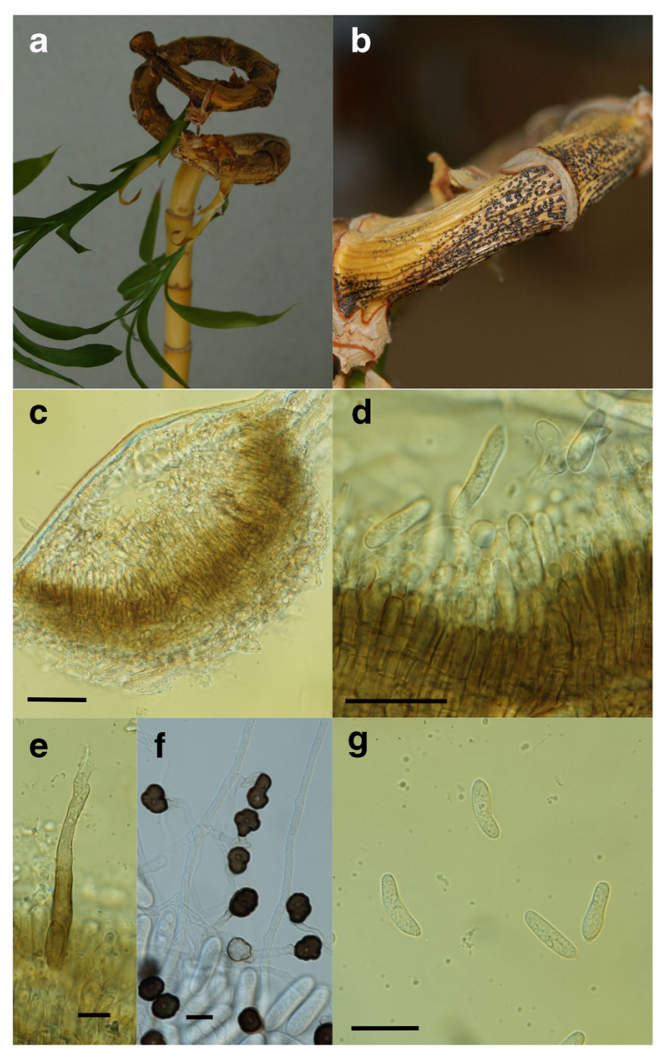

Fig. 1 Colletotrichum dracaenophilum on Dracaena braunii. a. D. braunii individual bearing anthracnose symptoms on stems. b. Close-up of anthracnose lesion crowded with acervuli of $C$. dracaenophilum. c. Cross section of acervulus of C. dracaenophilum (Bar $=10 \mu \mathrm{m})$; d. Layer of conidiophores producing conidia $(B a r=30 \mu \mathrm{m})$; e. Seta $(B a r=5 \mu \mathrm{m})$; f. Appressoria $(B a r=6 \mu \mathrm{m}) ;$ g. Conidia $(B a r=10 \mu \mathrm{m})$

electrophoresis in $0.8 \%$ agarose gels $(\mathrm{w} / \mathrm{v})$ stained with Gelred $^{\mathrm{TM}}$ (Biotium Inc, Hayward, CA, USA) and viewed under near ultra-violet light. Quantification was performed as described by the manufacturer. The following regions were PCR-amplified: Internal Transcribed Spacer (ITS) region primers ITS4 + ITS 5 (White et al. 1990); Actin (ACT) ACT-512F + ACT-783R (Carbone and Kohn 1999); Beta tubulin (Btub) - Bt-2b (Glass and Donaldson 1995) + T1 (O’Donnell and Cigelnik 1997). All PCR mixtures and conditions followed recommendations of Dream Taq ${ }^{\mathrm{TM}}$ PCR Master Mix manufacturer (Thermo Scientific $\AA$ ). Following PCR amplification, amplicons were visualized on $0.8 \%$ agarose gels stained with Gelred ${ }^{\mathrm{TM}}$ (Biotium Inc, Hayward, CA, USA) and viewed under near ultra-violet light and sizes of amplicons were determined against GeneRuler ${ }^{\mathrm{TM}}$ molecular marker (Thermo Scientific $\left({ }^{\circledR}\right)$. The PCR amplicons were subsequently diluted to $50 \mathrm{ng}$ in preparation for further DNA sequencing reactions. The DNA sequencing reactions used the same primers as those for the PCR. DNA sequencing amplicons were purified and sequenced by Macrogen-Korea (http://dna.macrogen.com/eng/). The ITS, ACT and Btub sequences were submitted to GenBank: KJ396954,
KJ653228 and KJ653227, respectively. The fungus had the following morphology: Internal mycelium intercelular, 3$5 \mu \mathrm{m}$ diam, branched, septate, hyaline. Conidiomata acervular, separate or confluent, $140-380 \times 135.5-240 \mu \mathrm{m}$, subepidermal. Setae sometimes transformed into conidiophores (ended in conidiogenous cell), subcylindrical, $55-95 \times 3 \mu \mathrm{m}$, tapering towards the rounded apex, 1-3 septate, pale to medium brown, smooth-walled. Conidiophores subcylindrical, 26-60×4-5 $\mu \mathrm{m}, 0-3$ septate, unbranched, dark brown, smooth; Conidiogenous cells terminal, integrated, enteroblastic, subcylindrical, 15-20 $\times 4$ $5 \mu \mathrm{m}$, subhyaline to brown. Conidia subclavate to cyclindrical, straight to somewhat curved, 16.5-31 $\times 5$ $8 \mu \mathrm{m}$, aseptate, hyaline; appressoria single or in loose groups, pale to dark brown, smooth-walled, clavate, ovate or irregular, margin entire or undulate, sometimes lobate, $6-$ $15 \times 4-10 \mu \mathrm{m}$.

In culture: fast-growing, (90 mm diam in 15 days); circular, flat to slightly convex, cottony to velvety, white, with orange mucilaginous and black punctuations distributed over colony, with diurnal zonation (visible only on PCA - potato carrotagar - under $12 \mathrm{~h}$ light regime); sporulation abundant.

The morphology of the fungus on lucky bamboo was equivalent to that described for $C$. dracaenophilum (Farr et al. 2006). This fungus is known to cause anthracnose on Dracaena sp. in Bulgaria (Farr and Rossman 2015) and China (Farr et al. 2006) and on D. braunii in Bulgaria (Bobev et al. 2008) and in China (Liu et al. 2014).

The Brazilian sequences of $C$. dracaenophilum had high identities to the ex-type sequences for ITS $100 \%$ homology (562/562 identities to NR119572) and Btub $100 \%$ homology (492/492 identities to JX519247). The ACT gene region had $96 \%$ homology to the ex-type specimen (248/257 identities to JX519238). We interpret this discrepancy as representing within-species variation not deserving special taxonomic recognition. Inoculated plants developed typical anthracnose symptoms 15 days after inoculation and pure cultures of $C$. dracaenophilum were obtained from diseased tissues.

Currently, Colletotrichum comprises more than a hundred species (Cannon et al. 2012). Fungi in this genus may be endophytic, pathogenic or saprophytic. Colletotrichum causes anthracnose diseases on a wide variety of woody and herbaceous plants (Waller et al. 2002). According to the new treatment for Colletotrichum spp. associated with Dracaena spp. (Damm et al. 2012), six species of Colletotrichum are accepted: C. boninense, C. dematium, C. dracaenae-fragrantis, C. dracaenophilum, C. gloeosporioides and C. petchii (Farr and Rossman 2012). The fungus collected in Brazil is morphologically and molecularly similar to $C$. dracaenophilum. In Brazil there is only one report of a species of Colletotrichum (C. gloeosporioides) on a member of the genus Dracaena $[D$. fragrans (Mendes and Urben 2014)], but this may belong to a different taxon under the modern concepts of Colletotrichum. Worldwide there have 
been reports of four species of Colletotrichum in association with Dracaena braunii, namely: $C$. dracaenophilum, $C$. gloeosporioides, C. petchii (Farr and Rossman 2012) and $C$. boninense (Farr et al. 2006). This is the first report of $C$. dracaenophilum on D. braunii in Brazil. This fungus species has also never been reported on any other host in Brazil.

Acknowledgments The present work was supported by Coordenação de Aperfeiçoamento de Pessoal de Nível Superior (CAPES - Brazil) and Conselho Nacional do Desenvolvimento Científico e Tecnológico (CNPq).

\section{References}

Bobev SG, Castlebury LA, Rossman AY (2008) First report of Colletotrichum dracaenophilum on Dracaena sanderiana in Bulgaria. Plant Dis 92:173-173

Cannon PF, Damm U, Johnston PR, Weir BS (2012) Colletotrichumcurrent status and future directions. Stud Mycol 73:181-213

Carbone I, Kohn LM (1999) A method for designing primer sets for speciation studies in filamentous ascomycetes. Mycologia 91:553-556

Damm U, Cannon PF, Woudenberg JHC, Johnston PR, Weir BS, Tan YP, Shivas RG, Crous PW (2012) The Colletotrichum boninense species complex. Stud Mycol 73:1-36

Farr DF, Rossman AY (2012) Systematic mycology and microbiology laboratory, ARS, USDA. Retrieved on March 25, 2015 from http:// nt.ars-grin.gov/fungaldatabases/

Farr DF, Aime MC, Rossman AY, Palm ME (2006) Species of Colletotrichum on Agavaceae. Mycol Res 110:1395-1408
Gams W, Hoekstra ES, Aptroot A (1998) CBS course of mycology. Baarn, Netherlands: Centraalbureau voor Schimmelcultures. $165 \mathrm{p}$

Glass NL, Donaldson G (1995) Development of primer sets designed for use with PCR to amplify conserved genes from filamentous ascomycetes. Appl Environ Microbiol 61:1323-1330

Gunathilake C, Abeywickrama KP (2011) Growth promotion and preservation of bare rooted plants of dracaena sanderiana for commercialization. Trop Agric Res Ext 14:1-4

Liu F, Cai L, Crous PW, Damm U (2014) The Colletotrichum gigasporum species complex. Persoonia 33:83-97

Mendes MAS, Urben, AF (2014) Fungos relatados em plantas no Brasil, Laboratório de Quarentena Vegetal. Brasília, DF: Embrapa Recursos Genéticos e Biotecnologia. http://pragawall.cenargen.embrapa.br/ aiqweb/michtml/fgbanco01.asp. Accessed 13 January 2014

O'Donnell K, Cigelnik E (1997) Two divergent intragenomic rDNA ITS2 types within a monophyletic lineage of the fungus Fusarium are nonorthologous. Mol Phylogenet Evol 7: $103-116$

Pereira JM, Barreto RW, Ellison CA, Maffia LA (2003) Corynespora cassiicola $\mathrm{f}$. sp. lantanae: a potential biocontrol agent from Brazil for Lantana camara. Biol Control 26:21-31

Rayner RW (1970) A mycological colour chart. Commonwealth mycological institute and British mycological society, Kew

Tropicos.org (2013) Missouri botanical garden. www.tropicos.com.br. Accessed 21 Aug 2013

Waller JM, Lenné JM, Waller SJ (2002) Plant pathologists's pocketbook. CABI, Wallingford

White TJ, Bruns T, Lee S, Taylor J (1990) Amplification and direct sequencing of fungal ribosomal RNA genes for phylogenetics. In: Innis MA, Gelfand DH, Sninsky JJ, White TJ (eds) PCR protocols: a guide tomethods and applications. San Diego, CA, USA, pp 315-322 